\title{
Influence of environmental variation on Atlantic Forest tree-shrub-layer phytogeography in southeast Brazil
}

\author{
Felipe Cito Nettesheim ${ }^{1,4}$, Luis Fernando Tavares de Menezes², Daniel Costa de Carvalho ${ }^{3}$, \\ Marilena Menezes Silva Conde ${ }^{3}$ and Dorothy Sue Dunn de Araujo ${ }^{1}$
}

Recebido em 15/07/2009. Aceito em 22/01/2010

\begin{abstract}
Influence of environmental variation on Atlantic Forest tree-shrub-layer phytogeography in southeast Brazil). This work assessed data from 32 forest sites in Rio de Janeiro and São Paulo, Brazil, using multivariate analysis to answer the question: Are there floristic patterns of the Atlantic Forest tree-shrub layer related to the Serra do Mar and the width of coastal plains in the states of Rio de Janeiro and São Paulo? Three multivariate analyses were performed to investigate the relationship between the tree-shrub flora and environmental variation in these 32 study areas. Our analyses demonstrated the influence of geo-climatic variation on floristic differentiation of tree and shrub species in Atlantic Forest regions generating groups of areas based on similar biotic and abiotic characteristics. These groups support the existence of floristic patterns within the states of São Paulo and Rio de Janeiro and reflect tree-shrub species substitution between the study areas as a consequence of annual rainfall, altitude, and mean annual temperature variation linked to a change in the position of the Serra do Mar and an increase in coastal plain width. Preferential species were cited for each group and should be considered in restoration and conservation programs for the phytoecological regions represented by the groups.
\end{abstract}

Key words: Atlantic rain forest, floristic composition, multivariate analyses, phytogeography

RESUMO - (Influência da variação ambiental sobre a fitogeografia do estrato arbóreo-arbustivo da Mata Atlântica em dois estados do sudeste brasileiro). O presente trabalho analisou dados de 32 remanescentes florestais nos estados do Rio de Janeiro e São Paulo, através de análises multivariadas para responder a pergunta: Existem padrões floristicos do estrato arbóreo-arbustivo da Floresta Atlântica relacionados a Serra do Mar e alargamento das planícies costeiras nos estados do Rio de Janeiro e São Paulo? Foram utilizadas três análises multivariadas para investigar as relações entre a flora arbóreo-arbustiva e a variação ambiental das 32 áreas. As análises demonstraram influência de alterações geo-climáticas sobre a diferenciação florística das espécies arbóreas e arbustivas da Mata Atlântica. Este fato permitiu gerar grupos com as áreas analisadas baseados em características bióticas e abióticas, sustentando a existência de padrões florísticos nos estados do Rio de Janeiro e São Paulo. Os grupos formados refletem a substituição das espécies arbóreo-arbustivas entre as áreas analisadas como conseqüência de variações da precipitação, altitude e temperatura média anual à medida que modifica o posicionamento da Serra do Mar e cresce a planície costeira. Para cada grupo foram designadas espécies preferenciais que devem ser consideradas em programas de restauração e conservação das regiões fitoecológicas por eles representadas.

Palavras-chave: Análise multivariada, composição florística, fitogeografia, Mata Atlântica

\section{Introduction}

Ecosystem fragmentation is one of the major causes of the loss of biodiversity on our planet. The Atlantic forest is the most threatened biome in Brazil, its degradation having been initiated in the $16^{\text {th }}$ century and accelerated with expansion of agriculture and fixation of Europeans and Africans along the Brazilian coast (SOS Atlantic Forest \& INPE 2002). Today this forest is one of the planet's 35 biodiversity hotspots, with high species richness and high levels of endemism, although it suffers from rapid reduction of intact habitats (Myers et al. 2000). There has been significant recent interest in studies that assess the consequences of forest fragmentation on biodiversity conservation, as many forests have been reduced to disconnected areas (Schellas \& Greenberg 1997, Viana et al. 1997). These studies have stimulated initiatives for the conservation of remnant areas, as in the case of the Atlantic forest that now occupies only eight percent of its original range (Galindo-Leal \& Câmara 2003).

A number of floristic studies in remnant forests on the southeastern Brazilian coast have demonstrated the heterogeneity of the biome as a whole, with greatest similarity between regions of equal forest formation (Peixoto et al. 1995, Sanchez et al. 1999, Moreno et al. 2003, Peixoto et al. 2004, Gomes et al. 2005, Guedes-Bruni et al. 2006b). Studies employing multivariate analyses to facilitate identification of ecological patterns in floristic data (Kent \& Coker 1992) have concentrated on phytogeographic relationships and geo-climatic influences in the southeastern part of the country. These studies have revealed important information about the Atlantic forest in that region, such as the floristic differences between ombrophilous and seasonal forests in relation to rainfall; greater similarities between ombrophilous and seasonal forests than with other forest formations; differentiation between ombrophilous and seasonal forests that can be attributed to altitude and temperature; a "gap" in the ombrophilous forest in northern Rio de Janeiro state due to this region's seasonal climate, which cannot be defined as a proper disjunction in distribution of tree species; and the existence of three floristic blocks in Rio de Janeiro state based on tree species of the Fabaceae family (OliveiraFilho \& Fontes 2000, Oliveira-Filho et al. 2005, H.C.Lima, unpublished data). Given the value of this kind of information for decision makers and agents involved in planning

\footnotetext{
1 Universidade Federal do Rio de Janeiro, Instituto de Biologia, Programa de Pós-Graduação em Ecologia, Laboratório de Ecologia Vegetal, Rio de Janeiro, RJ, Brasil

2 Universidade Federal do Espírito Santo, Centro Universitário Norte do Espírito Santo, Departamentos de Ciências da Saúde, Biológicas e Agrárias, São Mateus, ES, Brasil

3 Universidade Federal Rural do Rio de Janeiro, Departamento de Botânica, Seropédica, RJ, Brasil

${ }^{4}$ Corresponding author: felipe@citos.net
} 
conservation programs in southeastern Brazil, there is a real need for a better understanding of how the environment affects phytogeographic relationships between Atlantic forests remnants in Rio de Janeiro and São Paulo states.

Many of the remnant areas of Atlantic forest in Rio de Janeiro and São Paulo are located in the Serra do Mar and Mantiqueira mountain ranges, which are aligned subparallel to each other (Almeida \& Carneiro 1998). The Serra do Mar mountain range crosses these two states in a northeasterly direction, stretching from the southern coast of São Paulo state to northern coastal Rio de Janeiro. In São Paulo the mountain range generally remains close to the coastline and forms a natural barrier capturing orographic rains that fall on the narrow coastal plain and mountain slopes facing the ocean (Barbosa 2007). At Itacuruçá (Rio de Janeiro), the Serra do Mar mountain range advances into the interior of the state, receiving different names as it stretches to northern Rio de Janeiro. The inland orientation of Serra do Mar allows occurrence of a wider coastal plain in Rio de Janeiro than in São Paulo, which is then gradually replaced by tablelands in northern Rio de Janeiro. Changes in the orientation of Serra do Mar mountain range and widening of the coastal plain are attributed to the Guanabara Graben, which was formed by the erosion and retreat of the Atlantic Plateau scarps during the Paleocene era (Almeida \& Carneiro 1998).

Considering that the floristic composition of ombrophilous and seasonal forests within the Atlantic forest biome are related to climate variation (Oliveira-Filho \& Fontes 2000, Oliveira-Filho et al. 2005) and that environmental variation can influence climate (Leuschner 2000), the present study aims to answer the question: Are there floristic patterns of the Atlantic Forest tree-shrub layer related to Serra do Mar and widening of coastal plains in the states of Rio de Janeiro and São Paulo? In order to address to this question we tested the prediction that such floristic patterns do not exist, thus allowing us to accept or reject our null hypothesis.

\section{Material and methods}

Atlantic forest data -32 floristic studies from the states of Rio de Janeiro and São Paulo were selected (Fig. 1) to form two databases. The first consists of a binary matrix (presence/absence) of the tree and shrub species in the 32 areas. The second consists of environmental and geographic information on altitude (a), average annual rainfall (b), average annual temperature (c), average annual temperature variation (d), distance from the ocean (e), latitude - UTM (f), and longitude - UTM (g) of these sites. When these geo-environmental variables were not specified in the original publication, we consulted the authors of the papers, the National Meteorological Institute (2006) or DNMet (1992). The first database was fully revised to eliminate synonyms and errors in the presence/absence of species that could influence the results. In its final form, the matrix contained 1590 species.

Multivariate analysis - canonical correspondence analysis (CCA) was performed (ter Braak 1995) using Canoco for Windows Version 4.5 software program (ter Braak \& Smilauer 2002) to investigate the relationship between the tree flora (at the taxonomic level of species) and geo-environmental variables. After preliminary analysis of the data, variation in average annual temperatures (d) and distance from the ocean (e) were discarded from further analysis due to a weak correlation with the four axes ("intra-set" correlation $<0.4$ ) since they poorly explain variation within the data. We opted to maintain species that occurred in at least one of the 32 areas in the database, as their removal greatly reduced the eigenvalues of the axes. However, species considered discrepant with the main cloud of points in the CCA were eliminated during the analysis (Kent \& Coker 1992) so that the final principal matrix was composed of 1412 species. A Monte Carlo permutation test was performed to assess the significance of the correlations found by CCA.

We also performed a cluster analysis, using the Jaccard similarity coefficient, through unweighted pair-group method (UPGMA) or group average (McCune \& Grace 2002), in order to verify the existence of groups

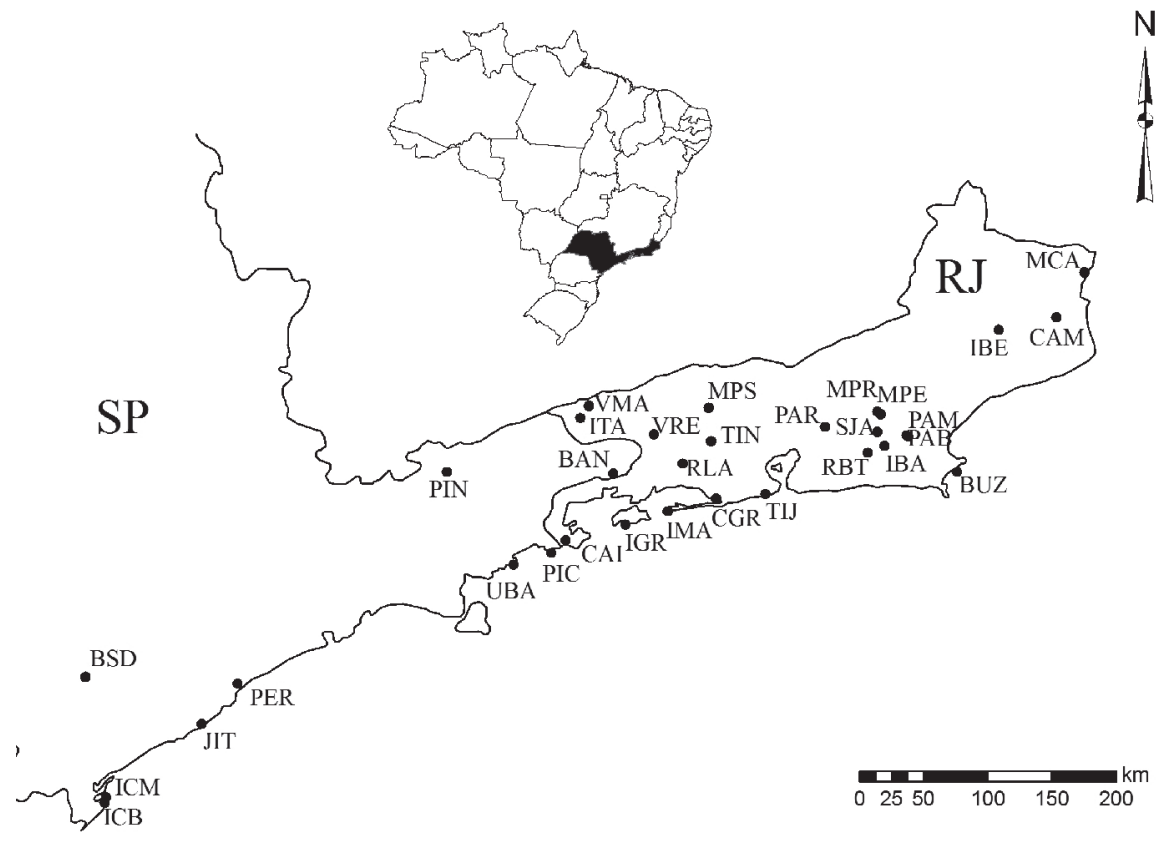

Figure 1. Map indicating the location of the 32 sites analyzed in this study. 
based on floristic similarities among the areas analyzed, using MVSP 3.1 - MultiVariate Statistical Package software program (Kovach 2004). TWINSPAN analysis with PC-ORD 4.10 program (McCune \& Mefford 1999) allowed us to identify key species among the groups formed by the cluster analysis (Kent \& Coker 1992).

\section{Results and discussion}

The Atlantic forest sites examined by multivariate analysis are listed in Table 1, and the results of the CCA analyses are shown in Tables 2 and 3. The eigenvalues encountered for the first two axes of the CCA were relatively high $(>0.4)$, indicating changes in species composition along the gradients synthesized in these ordination axes (ter Braak 1995). The cumulative percentage of variance explained by the axes was low $(17.6 \%)$, indicating a considerable amount of unexplained "noise". This type of situation is quite common for floristic data and does not diminish the significance of the species-environment relationship (Oliveira-Filho \& Fontes 2000). In fact, Pearson's correlations for taxa-environment were consistently high (Table 2) $(r>0.9)$. The Monte-Carlo permutation test indicated high significance $(<0.01)$ of the data expressed in the first canonical axis, as well as for all of the ordination axes considered together (Table 2).

The gradient expressed in the first canonical ordination axis is consistently correlated with longitude $(r=0.65)$, annual temperature $(r=0.62)$, and rainfall $(r=-0.63)$. The second axis showed consistent correlations with latitude $(r=0.83)$, altitude $(r=0.68)$, and longitude $(r=0.64)$. Consistent correlations were also observed between altitude and annual temperature $(r=-0.7)$; longitude and rainfall $(r$ $=-0.73)$; and latitude and longitude $(r=0.82)$ (Table 3). As such, the first ordination axis mainly reflects the change in floristic composition between the states of São Paulo and Rio de Janeiro, indicating a geographic gradient with higher average temperatures and lower altitude and rainfall with increasing longitude in a northeasterly direction. The second axis expresses primarily the gradual alteration of species related to changes in latitude and altitude (latitude diminishing towards the south, and altitude diminishing both towards the coastline and to the northeast). These results are in agreement with patterns observed in southeastern Brazil that indicated the influence of geo-environmental factors on the differentiation of the tree flora in that region (OliveiraFilho et al. 2005).

The relationship between environmental variables and species composition of the 32 sites of Atlantic forest is illustrated by the CCA diagram (Fig. 2). Three distinct groups can be identified: one group of areas (black squares) in the lower left quadrant are all located along (or very near to) the Serra do Mar range near the São Paulo coast, and they are united by a floristic pattern determined by high levels of rainfall, predominantly high temperatures, and low-to-medium altitudes; a group in the upper left quadrant (black triangles) formed by sites in both São Paulo and Rio de Janeiro is associated with high altitudes, low annual temperatures, and intermediate rainfall levels; a large group in the upper and lower right-hand quadrant (white circles) is formed by sites in the Serra do Mar (RJ), Guanabara Graben, coastal mountains, and northern region, all in Rio de Janeiro state, and are associated with low-to-average altitudes, lowto-intermediate rainfall, and high annual temperatures (Fig. 2). These results demonstrate that the floristic differentiation between areas of Atlantic forest in Rio de Janeiro and those in São Paulo are a result of differences in rainfall, altitude, and average annual temperature, and reinforces the role of geo-environmental variables in speciation (Gentry 1982, Huggett 1995, Oliveira-Filho et al. 2005).

Among the various environmental factors examined, rainfall plays a significant role in the floristic differentiation between São Paulo and Rio de Janeiro. The importance of rainfall in determining floristic composition has already been confirmed in extensive studies in the Neotropics and in the differentiation of ombrophilous and seasonal forests in the Atlantic forest biome of southeastern Brazil (Gentry 1982, Oliveira-Filho \& Fontes 2000). Rainfall decreases from São Paulo to Rio de Janeiro following the Serra do Mar range (which crosses the coastal region of São Paulo in a northeasterly direction) as the slopes become more distant from the coastline, thus causing decreasing influence on orographic rainfall, as the range approaches southern Rio de Janeiro (and northeastern São Paulo state), and allowing widening of the coastal plains known as Guanabara Graben (Almeida \& Carneiro 1998). This geographic situation translates into heavier rainfall on the coastal plains (and the slopes of the Serra do Mar range in São Paulo) and lighter rainfall in Rio de Janeiro state (Barbosa 2007). This variation in rainfall imposed by landform changes helps explain the differences observed between the Atlantic forest of São Paulo and Rio de Janeiro (Huggett 1995).

The heterogeneity of the Atlantic forest has been examined in various comparative studies employing cluster analysis (Peixoto et al. 2004, Carvalho et al. 2006b, Rolim et al. 2006). The use of this technique together with TWINSPAN analysis has confirmed and refined information generated by CCA. The interpretation of the dendrogram obtained in the similarity analysis is a subjective task that depends greatly on the researcher who must subdivide groups if there is compelling ecological evidence (Kent \& Coker 1992). As such, three consecutive cuts of the dendrogram defined the groups "A", "B", "C", "D", "E", "F", and "G". In the first cut, two principal groups (" $\mathrm{A}$ " and " $\mathrm{B}$ ") were identified; in the second cut, group " $\mathrm{B}$ " was subdivided into "C", "D", and "E"; and in the third cut, "E" was subdivided into "F" and "G" (Fig. 3).

Group "A" was separated from the group of dense ombrophilous forests ("B") and is composed mainly of seasonal forests (Fig. 3). According to the CCA, the four sites in this group are related by high temperatures, low rainfall, and low altitude. Although the CGR site is geographically distant from the other sites in this group 
Nettesheim et al: Influence of environmental variation on Atlantic Forest tree-shrub-layer phytogeography in southeast Brazil

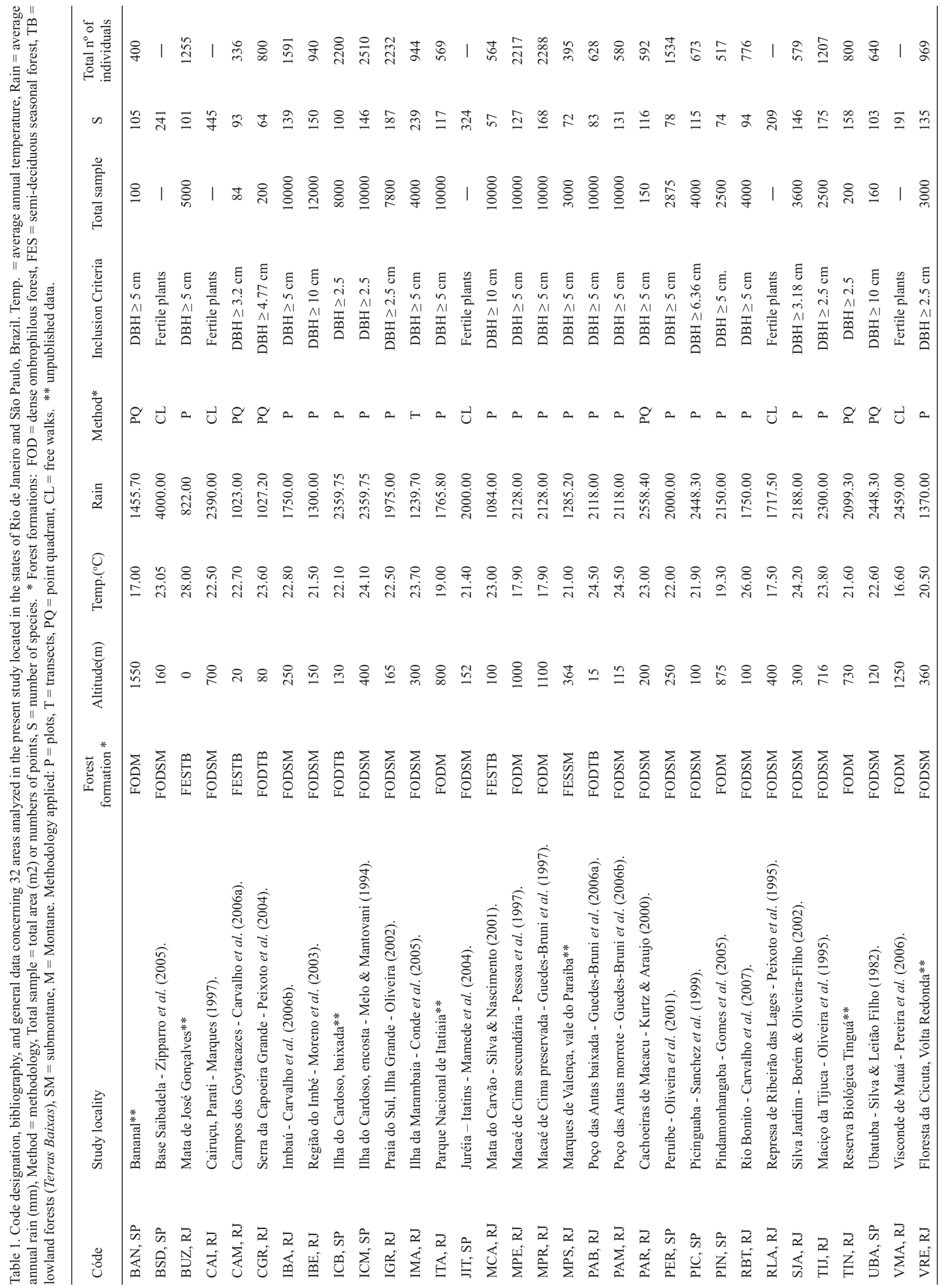


Table 2. Summary of the results of the canonical correspondence analysis (CCA) and Monte Carlo test with the arboreal flora and environmental variable in 32 areas of Atlantic Forest in the states of Rio de Janeiro and São Paulo.

\begin{tabular}{|c|c|c|c|c|}
\hline & Axis 1 & Axis 2 & Axis 3 & Axis 4 \\
\hline Eigenvalues & 0.465 & 0.423 & 0.283 & 0.261 \\
\hline Species Correlation- environment. & 0.976 & 0.976 & 0.970 & 0.943 \\
\hline Variance Accumulation of the species data (\%). & 5.7 & 10.9 & 14.4 & 17.6 \\
\hline Variance Accumulation of the species relationship - environment $(\%)$. & 27.6 & 52.7 & 69.5 & 85.0 \\
\hline
\end{tabular}

Monte Carlo Significance Test of the first canonical axis: 0.0006

Monte Carlo Significance Test of the sum of all of the canonical axes: 0.0002

Table 3. Results of the canonical correspondence analysis (CCA), providing intra-set and inter-set correlations for the first two axes, and the correlations between the environmental variables. Alt. = altitude, Prec. = average annual precipitation, Temp. = average annual temperature, Lat. = latitude; Long. = longitude.

\begin{tabular}{|c|c|c|c|c|c|c|c|c|c|}
\hline \multirow{2}{*}{ Geo-environmental Variable } & \multicolumn{2}{|c|}{ Intra-set Correlations } & \multicolumn{2}{|c|}{ Inter-set Correlations } & \multicolumn{5}{|c|}{ Geographic and climatic variables } \\
\hline & Axis 1 & Axis 2 & Axis 1 & Axis 2 & Alt. & Prec. & Temp. & Lat. & Long. \\
\hline Altitude & -0.51 & 0.68 & -0.52 & 0.70 & 1.00 & --- & --- & --- & --- \\
\hline Precipitation & -0.63 & -0.29 & -0.65 & -0.30 & 0.01 & 1.00 & --- & --- & --- \\
\hline Annual temperature & 0.62 & -0.54 & 0.63 & -0.55 & -0.70 & -0.02 & 1.00 & --- & --- \\
\hline Latitude & 0.45 & 0.83 & 0.46 & 0.85 & 0.30 & -0.45 & -0.21 & 1.00 & --- \\
\hline Longitude & 0.65 & 0.64 & 0.66 & 0.65 & 0.030 & -0.73 & 0.05 & 0.82 & 1.00 \\
\hline
\end{tabular}

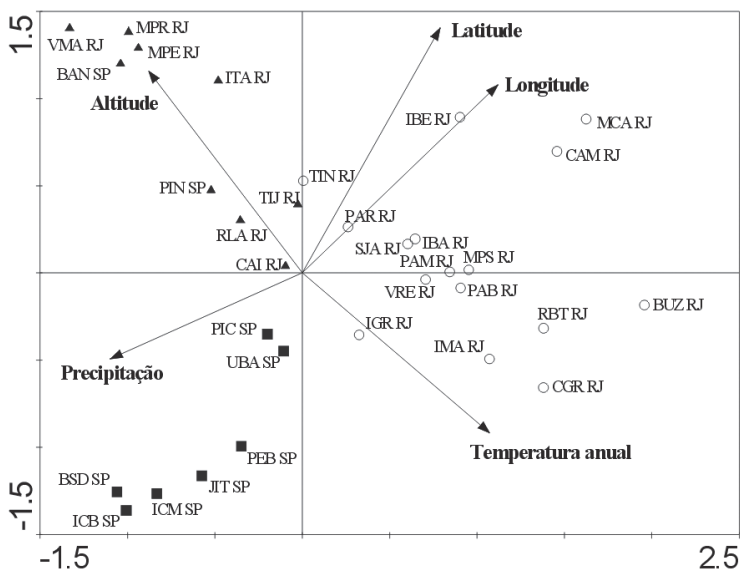

Figure 2. Diagram of canonical correspondence analysis (CCA). The grouping tendencies, demonstrating floristic patterns generated by geoenvironmental variation, are denoted by different symbols.

(south-central Rio de Janeiro), and is classified as a dense submontane ombrophilous forest (Veloso et al. 1991), it has environmental traits that lend a seasonal character to the site and contribute to differentiating it from other areas in São Paulo and Rio de Janeiro (as has been demonstrated in studies by Oliveira-Filho \& Fontes 2000; Moreno et al. 2003 ) - but makes it very similar to the rest of group " $\mathrm{A}$ " (Fig. 2). Group "A" has an associated flora composed of species such as Alseis pickelii Pilger \& Schmale, Acosmium lentiscifolium Vogel, Metrodorea brevifolia Engl., Pereskia grandifolia Haw., and Trichilia pseudostipularis (A. Juss.) C. DC., which were identified based on the results of TWINSPAN (Table 4).
Group "B" is composed of dense ombrophilous forests in the states of São Paulo and Rio de Janeiro (Fig. 3) with typical species such as Alchornea triplinervia (Spreng.) Müll. Arg., Cabralea cangerana Saldanha, Cariniana estrellensis (Raddi) Kuntze, Chrysophyllum flexuosum Mart., Euterpe edulis Mart., and Licania kunthiana Hook. f. (Table 4). The inclusion of the MPS site (classified as a semideciduous seasonal forest by Veloso et al. 1991) in group "B", as well as its proximity to the dense ombrophilous forests in the CCA diagram (Fig. 2), suggests that the flora is strongly influenced by the surrounding forest formations (Serra do Mar and Serra da Mantiqueira) and helps explain its inclusion in this group. The CCA diagram attributes greater rainfall, intermediate-to-high altitudes, and lower annual temperatures to group "B". It appears that these factors constitute the principal forces of floristic differentiation between the sites in groups "A" and "B".

Dense ombrophilous forest sites are generally grouped together when compared to other physiognomies (Carvalho et al. 2006b, Rolim et al. 2006), although natural heterogeneity allowed us to separate group "B" into sub-groups " $C$ ", " $D$ ", and "E" (Fig. 3).

Group "C" comprises areas of dense montane ombrophilous forest - DMOF (Fig. 3) and demonstrated the same tendency in CCA (Fig. 2). The similarities between the high montane forests of São Paulo and Rio de Janeiro draw attention to the relationship between the forests in these two mountain chains (Serra do Mar and Mantiqueira) that are separated by the Paraíba do Sul River valley. This observation was also supported by investigations undertaken 


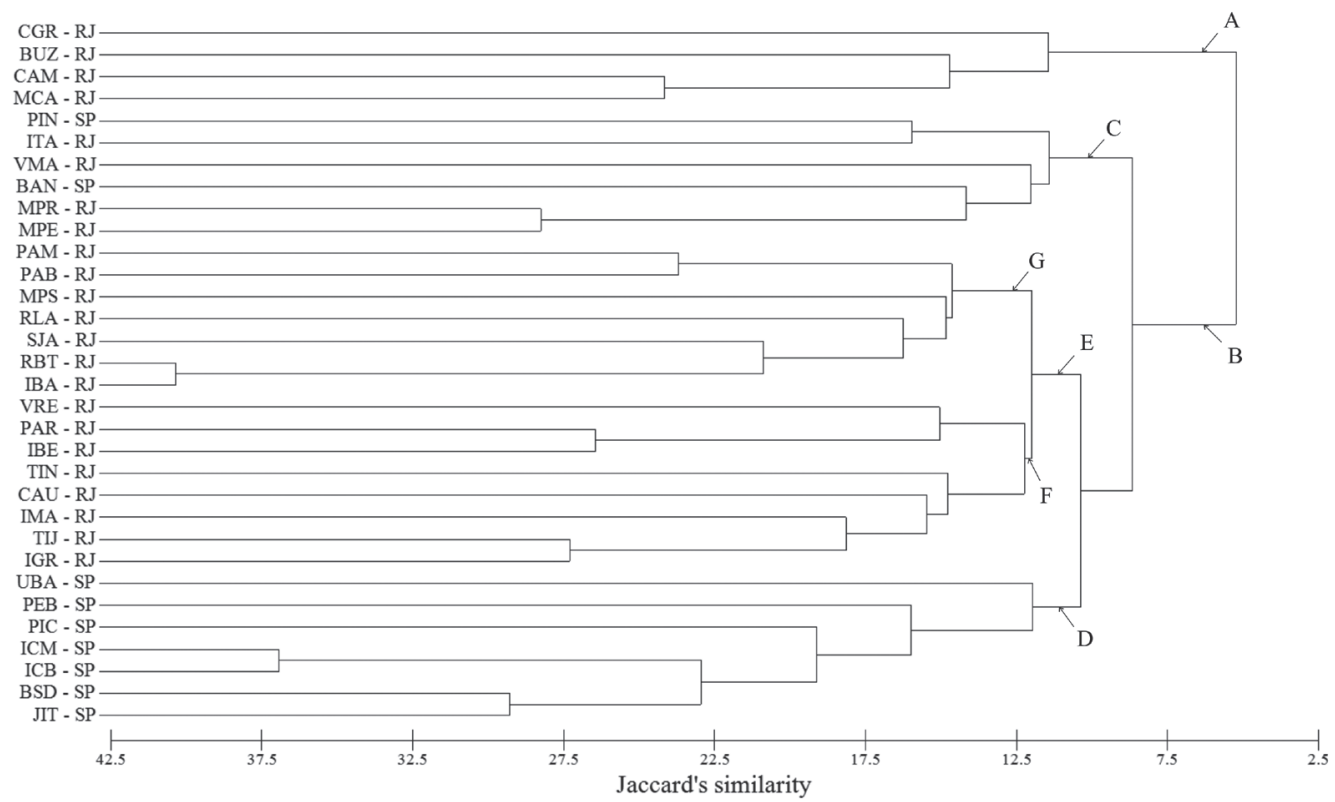

Figure 3. Cluster dendrogram of 32 sites of Atlantic forest in Rio de Janeiro and São Paulo. Associations are generated by group average after calculation of sites Jaccard coefficient similarity matrix. Groups are indicated by letters A, B, C, D, E, $\mathrm{F}$ and $\mathrm{G}$. Since there was no dendrogram similarity value smaller than $4 \%$ or higher than $42 \%$, axis range is shown from $2,5 \%$ to $42,5 \%$ to facilitate visualization.

in southeastern Brazil (Oliveira-Filho \& Fontes 2000), in the region of Bacias do Leste (Oliveira-Filho et al. 2005), and in Rio de Janeiro state (H.C.Lima, unpublished data). As such, our results corroborate the evolution of species in response to limiting factors imposed by high regional altitude and associated temperature variation (Webster 1995). This group comprises characteristic species such as Cordia ochnacea DC., Macropeplus ligustrinus (Tul.) Perkins, Ocotea vaccinioides (Meisn.) Mez, Vochysia rectiflora Warm., and Weinmannia paulliniifolia Pohl. (Table 4). Although the Tinguá site is classified as a dense montane ombrophilous forest (Veloso et al. 1991) it was grouped with forests found at medium-to-low altitudes. This may be the result of sampling in Tinguá, which was concentrated at lower elevations (Rodrigues, unpublished data).

The areas included in group " $\mathrm{D}$ " are located along the coast of São Paulo in the Serra do Mar range (with the exception of BSD in the Serra de Paranapiacaba range). These same localities were also grouped by CCA, mainly because of high rainfall, high temperatures, and low-tomedium altitudes (Fig. 2). The formation of group " $D$ ", and its distinction from group " $\mathrm{E}$ " in the cluster analysis, confirms a floristic differentiation between dense ombrophilous forests in São Paulo and Rio de Janeiro (Fig. 3). This differentiation may be related principally to rainfall, as suggested by the CCA diagram. The separation between the ombrophilous forests in the states of São Paulo and Rio de Janeiro had been detected in earlier studies (Oliveira-Filho \& Fontes 2000, Oliveira-Filho et al. 2005, Rolim et al. 2006). The present study emphasizes the determinant role of landscape in the floristic composition of the Atlantic forest in these states through its influence on regional rainfall patterns (Almeida \& Carneiro 1998, Barbosa 2007) that are in turn responsible for the observed difference in species composition. Some of the species indicated as typical for group " $\mathrm{D}$ " through TWINSPAN analysis include Ilex dumosa Reissek, Ixora burchelliana Müll. Arg., Pseudopiptadenia warmingii (Benth.) G.P. Lewis \& M.P. Lima, and Roupala paulensis Sleumer. (Table 4).

Group "E" unites dense ombrophilous forests at lowto-medium altitudes in Rio de Janeiro state having typical species such as Cordia trichotoma (Vell.) Arráb. ex Steud., Guarea kunthiana A. Juss., Miconia prasina (Sw.) DC., Ocotea schottii (Meisn.) Mez, Pradosia kuhlmannii Toledo, Sorocea hilarii Gaudich., and Xylopia sericea A. St.-Hil. (Table 4). As was suggested earlier, the floristic differences between groups " $\mathrm{E}$ " and " $\mathrm{D}$ " appear to result mainly from differences in rainfall between São Paulo and Rio de Janeiro. However, according to the CCA diagram (Fig. 2), it is also possible to detect the influence of higher annual temperatures on the sites in Rio de Janeiro included in group "E", as they are often located on the coastal plain region in the Guanabara Graben. As such, the floristic differences between groups "E" and "D" can be attributed to variation in rainfall and annual temperatures - reinforcing the influence of landscape features on the differentiation of the tree-shrub composition of forests in Rio de Janeiro and São Paulo. Group "E" can be further subdivided into " $F$ " and "G". This subdivision reflects a tendency towards a floristic differentiation between areas in the Guanabara Graben and those on the slopes of the 
Table 4. Species associated with the principal groups defined by the grouping analysis, selected on the basis of the TWINSPAN results and based on the species encountered in the 32 areas of Atlantic Forest.

\begin{tabular}{|c|c|}
\hline Group & Key Species \\
\hline $\mathbf{A}$ & $\begin{array}{l}\text { Acosmium lentiscifolium, Alseis involuta, Alseis pickelii, Aspidosperma multiflorum, Brasiliopuntia brasiliensis, Caesalpinia ferrea, Trichilia } \\
\text { pseudostipularis, Peltogyne discolor, Pereskia grandifolia, Metrodorea brevifolia, Spondias lutea, Parapiptadenia pterosperma, Neoraputia } \\
\text { alba, Pterygota brasiliensis, Trigoniodendron spiritusanctense, Rinorea laevigata. }\end{array}$ \\
\hline B & $\begin{array}{l}\text { Aegiphila sellowiana, Alchornea triplinervia, Alseis floribunda, Annona dolabripetala, Aparisthmium cordatum, Cabralea cangerana, } \\
\text { Calyptranthes lucida, Cariniana estrellensis, Cecropia glaziovi, Cinnamomum estrellense, Clethra scabra, Chrysophyllum flexuosum, Croton } \\
\text { floribundus, Cryptocarya moschata, Cupania oblongifolia, Ecclinusa ramiflora, Endlicheria paniculata, Eriotheca pentaphylla, Euterpe edulis, } \\
\text { Garcinia gardneriana, Gomidesia spectabilis, Guarea macrophylla, Handroanthus heptaphylla, Heisteria silvianii, Hirtella hebeclada, Lamanonia } \\
\text { ternata, Licania kunthiana, Licaria armeniaca, Machaerium nyctitans, Marlierea obscura, Matayba guianensis, Miconia cinnamomifolia, } \\
\text { Micropholis crassipedicellata, Mollinedia schottiana, Myrcia pubipetala, Ocotea dispersa, Ocotea elegans, Pouteria caimito, Psychotria nuda, } \\
\text { Quiina glaziovii, Sloanea guianensis, Sloanea monosperma, Tetrorchidium rubrivenium, Trichilia lepidota, Virola oleifera, Xylopia brasiliensis. }\end{array}$ \\
\hline $\mathbf{C}$ & $\begin{array}{l}\text { Casearia lasiophylla, Cordia ochnacea, Croton organensis, Daphnopsis fasciculata, Geonoma pohliana, Macropeplus ligustrinus, Meriania } \\
\text { claussenii, Miconia brunnea, Miconia octopetala, Myrsine gardneriana, Ocotea vaccinioides, Persea pyrifolia, Siphoneugena kiaerskoviana, } \\
\text { Stephanopodium organense, Tibouchina arborea, Tibouchina fissinervia, Trichipteris phalerata, Vochysia rectiflora, Weinmannia paulliniifolia. }\end{array}$ \\
\hline D & $\begin{array}{l}\text { Cordia sylvestris, Chomelia catharinae, Calycorectes acutatus, Erythroxylum ambiguum, Eugenia bocainensis, Eugenia multicostata, Eugenia } \\
\text { peruibensis, Gomidesia tijucensis, Geonoma gamiova, Ilex dumosa, Ixora burchelliana, Leandra mosenii, Machaerium scleroxylum, Malouetia } \\
\text { cestroides, Marlierea reitzii, Miconia cabussu, Miconia pyrifolia, Mollinedia uleana, Ossaea sanguinea, Ouratea multiflora, Pilocarpus } \\
\text { pauciflorus, Piper schenkii, Pouteria grandifolia, Protium kleinii, Pseudopiptadenia warmingii, Psychotria birotula, Roupala paulensis, } \\
\text { Rudgea heurchkii, Ruprechtia laxiflora. }\end{array}$ \\
\hline $\mathbf{E}$ & $\begin{array}{l}\text { Bauhinia forficata, Cordia trichotoma, Ficus clusiaefolia, Geissospermum laeve, Guapira nitida, Guarea guidonia, Guarea kunthiana, } \\
\text { Helicostylis tomentosa, Lacistema pubescens, Lecythis lanceolata, Melanoxylon brauna, Miconia calvescens, Miconia prasina, Mollinedia } \\
\text { puberula, Ocotea diospyrifolia, Ocotea schottii, Phyllostemonodaphne geminiflora, Piper arboreum, Plathymenia foliolosa, Pouteria } \\
\text { bangii, Pradosia kuhlmannii, Pseudopiptadenia inaequalis, Pseudolmedia hirtula, Rinorea guianensis, Siparuna arianeae, Sorocea hilarii, } \\
\text { Tovomitopsis paniculata, Xylopia sericea. }\end{array}$ \\
\hline $\mathbf{F}$ & $\begin{array}{l}\text { Aspidosperma ramiflorum, Carapa guianensis, Chrysophyllum gonocarpum, Eugenia mandiocensis, Eugenia microcarpa, Guatteria villosissima, } \\
\text { Ixora gardneriana, Licania tomentosa, Maytenus ardisiifolia, Miconia brasiliensis, Mollinedia longifolia, Mollinedia pachysandra, Myrcia laxiflora, } \\
\text { Oxandra martiana, Pausandra megalophylla, Picramnia ciliata, Piper rivinoides, Protium warmingiana, Psychotria brasiliensis, Psychotria } \\
\text { subspathacea, Qualea glaziovii, Rudgea langsdorfi, Rinorea physiphora, Siparuna apiosyce, Vochysia oppugnata, Zanthoxylum riedelianum. }\end{array}$ \\
\hline G & $\begin{array}{l}\text { Annona laurifolia, Apuleia leiocarpa, Cassia ferruginea, Chamaecrista ensiformis, Dalbergia nigra, Eugenia supraaxilaris, Guatteria } \\
\text { ferruginea, Handroanthus chrysotricha, Handroanthus umbellata, Jacaranda bracteata, Mabea fistulifera, Miconia hypoleuca, Ocotea } \\
\text { spectabilis, Peltogyne angustiflora, Vismia guianensis. }\end{array}$ \\
\hline
\end{tabular}

Serra do Mar range in Rio de Janeiro state. When studying leguminous tree species in the Atlantic forest of Rio de Janeiro, H.C.Lima (unpublished data) likewise observed differences between sites on the coastal plain and those on slopes at mid altitudes.

Group "F" has key species such as Carapa guianensis Aubl., Ixora gardneriana Benth., Vochysia oppugnata (Vell.) Warm., and Zanthoxylum riedelianum Engl.; while Apuleia leiocarpa (Vogel) J.F. Macbr., Dalbergia nigra (Vell.) Allemao ex Benth., and Mabea fistulifera Benth. are examples of species responsible for the formation of group "G" (Table 4). However, a clear distinction between these two groups, as detected by similarity analysis (Fig. 3 ), cannot be found when observing the CCA diagram (Fig. 2). This may be the result of differences between the types of analyses utilized. The CCA considers species as well as environmental variability, while similarity analysis considers only species. As such, the sites clustered by the dendrogram into groups "F" and "G" may not necessarily be closely aligned in the CCA diagram. Nonetheless, it is possible to perceive a general tendency for the areas composing group "F" to have greater altitudes but colder annual temperatures, while the members of group "G" have a greater tendency to occur at lower altitudes in areas that have higher annual temperatures (Fig. 2).

It is important to note that only qualitative data was used in the present study, and that quantitative data is generally more reliable as it takes both the occurrence and the abundance of species into consideration (Kent \& Coker 1992, McCune \& Grace 2002). Despite that our results demonstrate the existence of important floristic patterns in the Atlantic Forest tree-shrub layer in Rio de Janeiro and São Paulo states, indicating the substitution of species across these two states, which corroborates many aspects previously published in the scientific literature (Oliveira-Filho \& Fontes 2000, Moreno et al. 2003, Peixoto et al. 2004, Carvalho et al. 2006b, Rolim et al. 2006). These changes in floristic composition are related to transition of the Serra do Mar Range landscape as it moves further from the coastline (in a northeasterly direction), with consequent widening of the coastal plain (Guanabara Graben). The observed patterns of floristic differentiation were mainly attributed to high rainfall along the coast of São Paulo state, to high and medium average annual temperatures on coastal plain and mountain slopes in Rio de Janeiro, and to influence of altitudinal variation (Gentry 1982, Webster 1995, Oliveira-Filho et al. 
2005). Because of these patterns we were able to subdivide the 32 areas analyzed into seven different phytoecological regions of Atlantic Forest through the generation of groups, each of which had several preferential species selected on the basis of TWINSPAN results. Therefore, the information provided by this analysis (Table 4 ) is a valuable guideline for elaborating a list of species to be used in environmental restoration programs in the seven phytoecological regions here applied. This type of data can be very important for orienting conservation efforts in the Atlantic forest, although efforts should be made to address phytogeographical questions using quantitative data, since this information is more accurate and allows the confirmation or rejection of some of the patterns detected in current studies.

\section{Acknowledgments}

The authors would like to thank the Botany Department of the Biology Institute at Universidade Federal Rural of Rio de Janeiro for supporting this study; Cyl Farney Catarino de Sá, Miriam Cristina Alvarez Pereira, Jean Louis Valentin, Alexandre Fernandes Bamberg de Araújo, and the anonymous reviewers for their valuable suggestions regarding this work.

\section{Literature cited}

Almeida, F. F. M. de \& Carneiro, C. D. R. 1998. Origem e evolução da Serra do Mar. Revista Brasileira de Geociências 8: 135-150.

Barbosa, J. P. M. 2007. Mudanças climáticas e distribuição espacial da precipitação na Serra do Mar - Análises a partir de séries históricas de precipitação e sistema de informação geográfica (SIG). Caminhos de Geografia 8: 67-81.

Borém, R.A.T. \& Oliveira-Filho, A.T. 2002. Fitossociologia do estrato arbóreo em uma toposseqüência alterada de Mata Atlântica, Silva Jardim, RJ. Revista Árvore 26: 727-742.

Carvalho, F.A.; Braga, J.M.A.; Gomes, J.M.L.; Souza, J.S. \& Nascimento, M.T. 2006a. Comunidade arbórea de uma floresta de baixada aluvial no Município de Campos dos Goytacazes, RJ. Cerne, Lavras 12: 157-166.

Carvalho, F.A.; Nascimento, M.T. \& Braga, J.M.A. 2006b. Composição e riqueza floristica do componente arbóreo da Floresta Atlântica submontana na região de Imbaú, Município de Silva Jardim, RJ. Acta Botanica Brasilica 20: 727-740.

Carvalho, F. A.; Nascimento, M. T. \& Braga, J. M. A. 2007. Estrutura e composição floristica do estrato arbóreo de um remanescente de Mata Atlântica Submontana no município de Rio Bonito, RJ, Brasil (Mata Rio Vermelho). Revista Árvore 31: 717-730.

Conde, M.M.S.; Lima, H.R.P. \& Peixoto, A.L. 2005. Aspectos florísticos e vegetacionais da Marambaia, Rio de Janeiro, Brasil. Pp. 133-168. In: L.F.T. Menezes; A.L. Peixoto \& D.S.D. Araujo (eds.). História Natural da Marambaia. Seropédica, Editora da UFRuralRJ.

DNMET - Departamento Nacional de Meteorologia. 1992. Normais climatológicas (1961-1990). Brasília, Ministério da Agricultura.

Galindo-Leal, C. \& Câmara, I.G. 2003. Atlantic Forest hotspot status: an overview. Pp. 3-11. In: C. Galindo-Leal \& I. Câmara (eds.). The Atlantic Forest of South America. Washington, Center for Applied Biodiversity Science.

Gentry, A.H. 1982. Patterns of Neotropical Plant Species Diversity. Evolutionary Biology 15: 1-84

Gomes, E.P.C.G.; Fisch, S.T.V. \& Mantovani, W. 2005. Estrutura e composição do componente arbóreo na Reserva Ecológica do Trabiju, Pindamonhangaba, SP, Brasil. Acta Botanica Brasilica 19: 451-464.

Guedes-Bruni, R.R.; Pessoa, S.V.A. \& Kurtz, B.C. 1997. Florística e estrutura do componente arbustivo-arbóreo de um trecho preservado de floresta Montana na R. E. de Macaé de Cima. Pp. 127-145. In: H.C. Lima \& R.R. Guedes-Bruni (eds.). Serra de Macaé de Cima: diversidade, florística e conservação em Mata Atlântica. Rio de Janeiro, Jardim Botânico do Rio de Janeiro.
Guedes-Bruni, R.R.; Neto, S.J.S.; Morim, M.P. \& Mantovani, W. 2006a. Composição florística e estrutura de trecho de Floresta Ombrófila Densa Atlântica Aluvial na Reserva Biológica de Poço das Antas, Silva Jardim, Rio de Janeiro, Brasil. Rodriguésia 57: 413-428.

Guedes-Bruni, R.R.; Neto, S.J.S.; Morim, M.P. \& Mantovani, W. 2006b. Composição florística e estrutura de dossel em trecho de floresta ombrófila densa atlântica sobre morrote mamelonar na Reserva Biológica de Poço das Antas, Silva Jardim, Rio de Janeiro, Brasil. Rodriguésia 57: 429-442.

Huggett, R.J. 1995. Geoecology, an evolutionary approach. London, Routledge.

INMET. 2006. Climatologia. http://www.inmet.gov.br/climatologia (Acesso em: 11/2006).

Kent, M. \& Coker, P. 1992. Vegetation Description and Analysis: a practical approach. London, Belhaven.

Kovach, W.L. 2004. Multivariate Statistical Package. Version 3.1 for Windows.

Kurtz, B.C. \& Araujo, D.S.D. de 2000. Composição floristica e estrutura do componente arbóreo de um trecho de Mata Atlântica na Estação Ecológica Estadual do Paraíso, Cachoeiras de Macacu, Rio de Janeiro, Brasil. Rodriguésia 51: 69-112.

Leuschner, C. 2000. Are high elevation in tropical mountains arid environments for plants? Ecology 81: 1425-1436.

McCune, B. \& Grace, J.B. 2002. Analysis of Ecological Communities. Gleneden Beach, MjM Software Design.

McCune, B. \& Mefford, M.J. 1999. PC-ORD. Multivariate analysis of ecological data, version 4.10. Gleneden Beach, MjM Software Design.

Mamede, M.C.H.; Cordeiro, I.; Rossi, L.; Melo M.M.R.F. \& Oliveira, R.J. 2004. Mata Atlântica. Pp. 115-132. In: O.A.V. Marques \& W. Duleba (eds.). Estação Ecológica Juréia-Itatins Ambiente Físico, Flora e Fauna. São Paulo, Editora Holos.

Marques, M. M. do C. 1997. Mapeamento da cobertura vegetal e listagem das espécies ocorrentes na Area de Proteção Ambiental de Cairuçu, Município de Parati, RJ. Rio de Janeiro, Instituto de Pesquisas Jardim Botânico do Rio de Janeiro.

Melo, M.M.R.F. \& Mantovani, W. 1994. Composição floristica e estrutura de trecho de mata atlântica de encosta, na Ilha do Cardoso, Cananéia, SP. Boletim do Instituto de Botânica 9: 107-158.

Moreno, M.R.; Nascimento, M.T. \& Kurtz, B.C. 2003. Estrutura e composição florística do estrato arbórea em duas matas altitudinais na mata atlântica de encosta da região do Imbé, RJ. Acta Botanica Brasilica 17: $371-386$.

Myers, N., Mittermeier, R.A., Mittermeier, C.G., Fonseca, G.A.B. \& Kent, J. 2000. Biodiversity hotspots for conservation priorities. Nature 403: 853-858.

Oliveira, R. de J.; Mantovani, W \& Melo, M. M. R. F. 2001. Estrutura do componente arbustivo-arbóreo da floresta atlântica de encosta, Peruíbe, SP. Acta Botanica Brasilica 15: 391-412.

Oliveira, R.R.; Zaú, A.S.; Lima, D.F.; Silva, M.B.R.; Vianna, M.C.; Sodré, D.O. \& Sampaio, P.D. 1995. Significado ecológico da orientação de encostas no maciço da Tijuca, Rio de Janeiro. Oecologia Brasiliensis 1: $523-541$.

Oliveira, R.R. 2002. Ação antropica e resultantes sobre a estrutura e composição da Mata Atlântica na Ilha Grande, RJ. Rodriguésia 53: 33-58.

Oliveira-Filho, A.T. \& Fontes, M.A.L. 2000. Patterns of floristic differentiation among Atlantic Forest in southeastern Brazil and the influence of climate. Biotropica 32: 793-810.

Oliveira-Filho, A.T.; Neto, E.T.; Carvalho, W.A.C.; Werneck, M.; Brina, A.E.; Vidal, C.V.; Rezende, S.C. \& Pereira, J.A.A. 2005. Análise florística do compartimento arbóreo de áreas de floresta atlântica sensu lato na região das bacias do leste. Rodriguésia 56: 185-235.

Peixoto, A.L.; Rosa, M.M.T. da; Barbosa, M.R.V. \& Rodrigues, H.C. 1995. Composição florística da área em torno da represa de Ribeirão das Lajes, Rio de Janeiro, Brasil. Revista Universidade Rural, Série Ciência da Vida 17: 51 - 74.

Peixoto, G.L.; Martins, S.V.; Silva, A.F.; Silva, E. 2004. Composição florística do componente arbóreo de um trecho de Floresta Atlântica na Área de Proteção Ambiental da Serra da Capoeira Grande, Rio de Janeiro, RJ, Brasil. Acta Botanica Brasilica 18: 151-160. 
Pereira, I. M.; Oliveira-Filho, A. T.; Botelho, S. A.; Carvalho, W. A. C.; Fontes, M. A. L.; Schiavini, I. \& Silva, A. F. da. 2006. Composição floristica do compartimento arbóreo de cinco remanescentes florestais no Maciço do Itatiaia, Minas Gerais E Rio de Janeiro. Rodriguésia 57: $103-126$.

Pessoa, V.A. De; Guedes-Bruni, R; Kurtz, B.C. 1997. Florística e estrutura do componente arbustivo-arbóreo de um trecho preservado de floresta Montana na Reserva Ecológica de Macaé de Cima. Pp. 1147-167. In: H.C. Lima \& R.R. Guedes-Bruni (eds.). Serra de Macaé de Cima: diversidade, florística e conservação em Mata Atlântica. Rio de Janeiro, Instituto de Pesquisas Jardim Botânico do Rio de Janeiro.

Rolim, S.G.; Ivanauskas, N.M.; Rodrigues, R.R.; Nascimento, M.T. Gomes, J.M.L.; Folli, D.A. \& Couto, H. T. Z. 2006. Composição Floristica do estrato arbóreo da Floresta Estacional Semidecidual na Planície Aluvial do rio Doce, Linhares, ES, Brasil. Acta Botanica Brasilica 20: $549-561$.

Schellas, J. \& Greenberg, R. 1997. Forest patches in tropical landscapes. Washington, Island Press.

Sanchez, M.; Pedroni, F.; Leitão-Filho, H.F. \& César, O. 1999. Composição floristica de um trecho de floresta ripária na Mata Atlântica em Picinguaba, Ubatuba, SP. Revista Brasileira de Botânica 22: 31-42.

Silva, A.F. \& Leitão-Filho, H.F. 1982. Composição florística e estrutura de um trecho de mata atlântica de encosta no município de Ubatuba (SP). Revista Brasileira de Botânica 5: 43-52.
Silva, G.C. \& Nascimento M.T. 2001. Fitossociologia de um remanescente de mata sobre tabuleiros no norte do estado do Rio de Janeiro. Revista Brasileira de Botânica 24: 51-62.

SOS Mata Atlântica \& INPE. 2002. Atlas dos Remanescentes Florestais da Mata Atlântica - Período 1995-2000 - Relatório Final. São Paulo, Fundação SOS Mata Atlântica \& Instituto Nacional de Pesquisas Espaciais.

ter Braak, C.J.F. 1995. Ordination. Pp. 91-173. In: R.H.G. Jongman, C.J.F. ter Braak \& O.F.R. van Tongeren (eds.). Data analysis in community and landscape ecology. Cambridge, Cambridge University Press.

ter Braak, C.J.F. \& Smilauer, P. 2002. Canoco for Windows Version 4.5. Wageningen, Biometris - Plant research international.

Veloso, H.P.; Rangel Filho, A.L.R. \& Lima, J.C.A. 1991. Classificação da vegetação Brasileira adaptada a um sistema universal. Rio de Janeiro, Instituto Brasileiro de Geografia e Estatística.

Viana, V.M.; Tabanez, A.J.A. \& Batista, J.L. 1997. Dynamics and restoration of forest fragments in Brazilian Atlantic moist forest. Pp. 351-365. In: Laurance, W.F. \& Bierregaard Jr., R.O (eds.). Tropical forest remnants. Ecology, management and conservation of fragmented communities. Chicago, The University of Chicago Press.

Webster, G.L. 1995. The panorama of Neotropical cloud forests. Pp. 5377. In: S.P. Churchill; H. Balslev; E. Forero \& J.L. Luteyn (eds.) Biodiversity and conservation of Neotropical montane forests. Neotropical Montane Forest Biodiversity and Conservation Symposium 1. New York, New York Botanical Garden. 